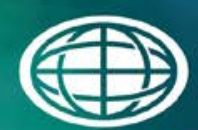

Savannah River

National Laboratory "

OPERATED BY SAVANNAH RIVER NUCLEAR SOLUTIONS

\title{
Glass Frit Clumping and Dusting
}

\author{
J. L. Steimke
}

September 2013

SRNL-STI-2013-00412, Revision 0 


\section{DISCLAIMER}

This work was prepared under an agreement with and funded by the U.S. Government. Neither the U.S. Government or its employees, nor any of its contractors, subcontractors or their employees, makes any express or implied:

1. warranty or assumes any legal liability for the accuracy, completeness, or for the use or results of such use of any information, product, or process disclosed; or

2. representation that such use or results of such use would not infringe privately owned rights; or

3. endorsement or recommendation of any specifically identified commercial product, process, or service.

Any views and opinions of authors expressed in this work do not necessarily state or reflect those of the United States Government, or its contractors, or subcontractors.

\section{Printed in the United States of America \\ Prepared for U.S. Department of Energy}


SRNL-STI-2013-00412

Revision 0

Keywords: DWPF, SME, frit

Retention: Permanent

\section{Glass Frit Clumping and Dusting}

J. L. Steimke

September 2013

Prepared for the U.S. Department of Energy under 


\title{
REVIEWS AND APPROVALS
}

\section{AUTHORS:}

\author{
J. L. Steimke, Advanced Characterization \& Processing \\ Date
}

TECHNICAL REVIEW:

M. R. Duignan, Engineering Process Development, Reviewed Per E.7, 2.60

Date

\section{APPROVAL:}

D. R. Click, Manager

Date

Processing Technology Programs

S. L. Marra, Manager

Date

Environmental \& Chemical Process Technology Research Programs

E. J. Freed, Manager

Date

SRR Engineering 


\section{EXECUTIVE SUMMARY}

DWPF mixes a slurry of glass frit (Frit 418) and dilute (1.5 wt\%) formic acid solution with high level waste in the Slurry Mix Evaporator (SME). There would be advantages to introducing the frit in a nonslurry form to minimize water addition to the SME, however, adding completely dry frit has the potential to generate dust which could clog filters or condensers. Prior testing with another type of frit, Frit 320, and using a minimal amount of water reduced dust generation, however, the formation of hard clumps was observed. To examine options and behavior, a TTQAP [McCabe and Stone, 2013] was written to initiate tests that would address these concerns. Tests were conducted with four types of glass frit; Frit 320, DWPF Frit 418, Bekeson Frit 418 and Multi-Aspirator Frit 418. The last two frits are chemically identical to DWPF Frit 418 but smaller particles were removed by the respective vendors. Test results on Frit Clumping and Dusting are provided in this report. This report addresses the following seven questions. Short answers are provided below with more detailed answers to follow.

1. Will the addition of a small amount of water, $1.5 \mathrm{wt} \%$, to dry DWPF Frit 418 greatly reduce the dust generation during handling at DWPF?

a. Yes, a small scale test showed that adding a little water to the frit greatly reduced dust generation during handling.

2. Will the addition of small amounts of water to the frit cause clumping that will impair frit handling at DWPF?

a. No, not with Frit 418. Although clumps were observed to form when $1.5 \mathrm{wt} \%$ water was mixed with DWPF Frit 418, then compressed and air-dried overnight, the clumps were easily crushed and did not form the hardened material noted when Frit 320 was tested.

3. What is the measured size distribution of dust generated when dry frit is handled? (This affects the feasibility and choice of processing equipment for removing the dust generating fraction of the frit before it is added to the SME.)

a. The size distribution for the dust removed from fresh DWPF Frit 418 while it was being shaken in a small scale LabRAM test was measured. The median size on a volume basis was $7.6 \mu \mathrm{m}$ and $90 \%$ of the frit particles were between 1.6 and $28 \mu \mathrm{m}$. The mass of dust collected using this test protocol was much less than $1 \%$ of the original frit.

4. Can the dust be removed in a small number of processing steps and without the larger frit particles continuing to spall additional dust sized particles?

a. Test results using a LabRAM were inconclusive. The LaRAM performs less efficient particle size separation than the equipment used by Bekeson and Multi-Aspirator.

5. What particle size of frit is expected to create a dust problem?

a. The original criterion for creating a dusting problem was those particle sizes that were readily suspended when being shaken. For that criterion calculations and Microtrac size analyses indicated that particles smaller than $37 \mu \mathrm{m}$ are likely dust generators. Subsequently a more sophisticated criterion for dust problem was considered, particle sizes that would become suspended in the air flow patterns inside the SME and possibly plug the condenser. That size may be larger than $37 \mu \mathrm{m}$ but has not yet been determined.

6. If particles smaller than $37 \mu \mathrm{m}$ are removed will bulk dust generation be eliminated?

a. Video-taped tests were performed using three gallons each of three types of frit 418, DWPF frit, Bekeson frit and Multi-Aspirator frit. Frit was poured through air from a height of approximately eight feet into a container half filled with water. Pouring Bekeson frit or Multi-Aspirator frit generated markedly less visible dust, but there was still a significant amount, which still has the potential of causing a dust problem. 
7. Can completely dry frit be poured into the SME without having dust plug the condenser at the top of the vessel?

a. Because of the complexity of air currents inside the SME and the difficulty of defensible size scaling a more prototypical test will be required to answer this question. We recommend construction of a full scale mockup of the top half of the SME with a shallow basin of water at the bottom and a simulated condenser at the top. It could be made from simple materials such as PVC pipe, cardboard and clear plastic and tested with dry frit. Depending on results, this may need to be coupled with the proposed pneumatic transfer system. 


\section{TABLE OF CONTENTS}

LIST OF FIGURES viii

LIST OF ABBREVIATIONS... ix

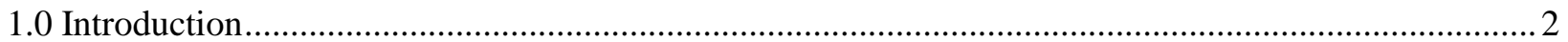

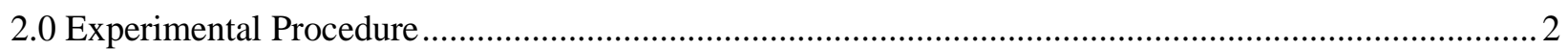

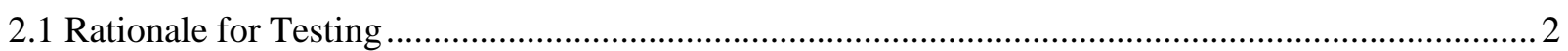

2.2 Procedures

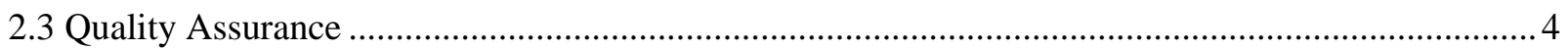

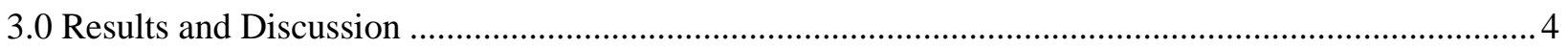

3.1 Will the addition of water greatly reduce dust generation? ........................................................... 4

3.2 If water is added will it cause the frit to clump? ........................................................................... 5

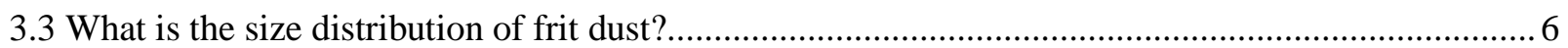

3.4 Can dust be removed from frit without generating fresh dust? ..................................................... 9

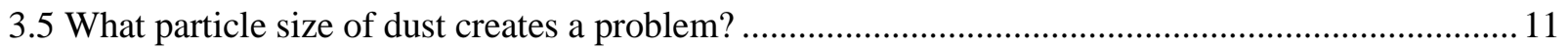

3.6 Can removal of small particles eliminate or nearly eliminate dust generation?.............................. 15

3.7 Can dry frit be poured into the SME without plugging the condenser? ......................................... 16

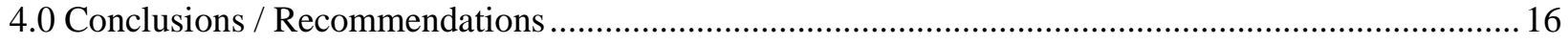

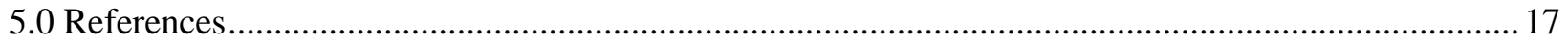




\section{LIST OF FIGURES}

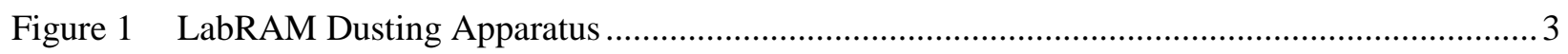

Figure 2 Observation Window Showing DWPF Frit 418 Dust from dry test (above, no water added) and wet test (below, water added) …............................................................................................... 5

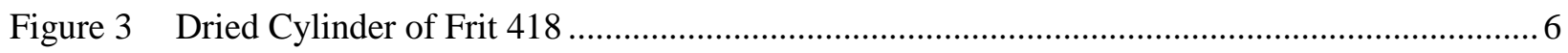

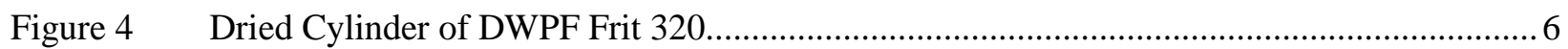

Figure 5 Scanning Electron Micrograph of Frit Dust from dry test collected in window........................ 7

Figure 6 Particle Size Distribution of Frit Dust ................................................................................ 8

Figure 7 Bimodal Frit Size Distribution from frit dust collected at 10\% intensity for extended duration 10

Figure 8 Size Distributions for Three Types of Frit, Full Scale .......................................................... 12

Figure 9 Size Distributions for Three Types of Frit, Expanded Scale ................................................13

Figure $10 \quad$ Terminal Velocities for Sphere in Air and Water ............................................................ 14 


\section{LIST OF ABBREVIATIONS}

$\begin{array}{ll}\text { ACTL } & \text { Aiken County Technology Laboratory } \\ \text { DWPF } & \text { Defense Waste Processing Facility } \\ \text { SME } & \text { Slurry Mix Evaporator } \\ \text { SRNL } & \text { Savannah River National Laboratory } \\ \text { SRS } & \text { Savannah River Site }\end{array}$




\subsection{Introduction}

The SRS Defense Waste Processing Facility (DWPF) mixes a slurry of glass frit (Frit 418) and dilute (1.5 wt\%) formic acid solution with high level waste in the Slurry Mix Evaporator (SME). The slurry is later sent to the DWPF Glass Melter and the resulting molten glass is cast into canisters for long term storage. There would be advantages to introducing the frit in a non-slurry form to minimize the mass of water added to the SME, however, adding completely dry frit has the potential to generate dust which could clog filters or condensers. Prior vendor testing with another type of frit, Frit 320, using a minimal amount of water reduced dust generation, however, the frit tended to form hard clumps. To evaluate options and behavior, tests were performed to examine these concerns.

Iverson [1983] noted that Frit 131 can absorb water from the atmosphere and form hard layers six inches thick or more and Frit 165 absorbs water to form lumps. (Neither of these frits is currently used at SRS. Frit 131 gels when mixed with water and readily leaches alkali.) Baron [1987] described successful testing of hardware to transport dry Frit 168 from the bins in which it was delivered to the Frit Slurry Make-up Tank from which it is later transferred to the SME. The hardware consisted of a bin inverter, screw conveyor and bucket elevator. All bins of frit were supplied with desiccant cartridges. Also half of the bins were treated with colloidal silica, which is a flowability promoter. However, the frit from all bins was free flowing and easy to convey; therefore, the use of a flowability promoter was not recommended. Lambert and Hansen [2010] tested the idea of adding a small amount of water to eight types of dry frit to reduce dust generation. Adding about $1 \mathrm{wt} \%$ of water to the frit greatly reduced dust generation but also decreased the ability of the frit to flow freely. These historical results show that changes in frit formulation can possibly alter the tendency of the frit to clump.

\subsection{Experimental Procedure}

\subsection{Rationale for Testing}

Seven questions arose during discussions of the introduction of dry or nearly dry frit to the SME that were addressed with testing.

1. Will the addition of a small amount of water, $1.5 \mathrm{wt} \%$, to dry DWPF Frit 418 greatly reduce the dust generation during handling at DWPF?

2. If water is added to the frit and compacted and the frit is allowed to dry, will it cause clumping that will impair frit handling at DWPF?

3. What is the measured size distribution of dust generated when completely dry frit is handled? (This affects the feasibility and choice of processing equipment for removing the dust generating fraction of the frit before it is added to the SME.)

4. Can the dust in the previous question be removed in a small number of processing steps and without the larger frit particles continuing to spall additional dust sized particles?

5. What particle size of frit is expected to create a dust problem?

6. If particles below that size are removed, will dust generation be eliminated or nearly eliminated during handling?

7. Can completely dry frit be poured into the SME without having frit dust plug the condenser at the top of the vessel? 


\subsection{Procedures}

A series of tests were devised that were conducted at Aiken County Technical Laboratory (ACTL) to answer the questions. Most of the tests used the Resodyn LabRAM shaker apparatus which provided a reproducible method for creating conditions that could generate dust. Frit and dust size distributions were measured using Microtrac. Samples were submitted for size analysis in slurry form in very dilute nitric acid to prevent possible dissolution of frit particles.

1. Quantification of the degree of dust reduction accomplished by the addition of water used the R\&D Direction listed in Appendix A. This testing used the LabRAM acoustic mixer in ACTL with DWPF Frit 418 and the apparatus is shown in Figure 1. On April 10, 2013 one hundred grams of dry Frit 418 were added to the container in the LabRAM and shaken at $10 \%$ intensity for ten minutes. This intensity was just sufficient to fully mobilize the frit particles. During this period, air was drawn at ambient pressure through the container, a glass Observation Window (1" diameter and 3" long) and a filter in a housing at a flowrate of $400 \mathrm{sccm}$ using a partial vacuum located downstream of the filter. After ten minutes the window was observed and photographed. Later the filter, filter holder and window were reweighed. The test was repeated using frit to which $1.5 \mathrm{wt} \%$ water had been added.

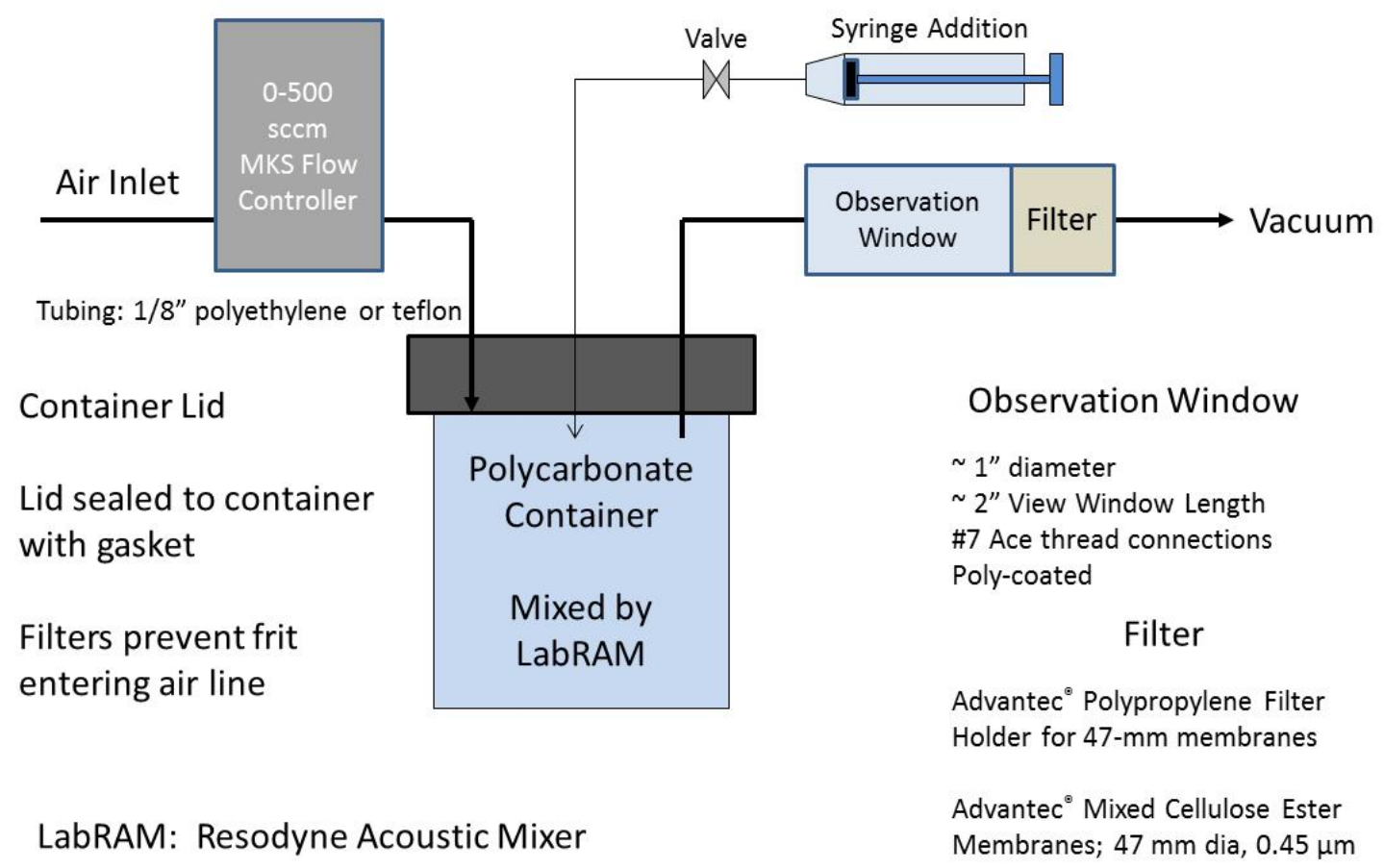

Figure 1 LabRAM Dusting Apparatus

2. Quantification of the degree of clumping used the R \& D Direction in Appendix B. The technique was to compress a small cylinder of damp resin and allow it air dry overnight. This was done both with Frit 418 and another frit, Frit 320, for which clumping had been observed. The next day the mass required to crush the dried cylinder was measured. The mass was distributed over $1 \mathrm{~cm}^{2}$ and was applied vertically downward on the top of the cylinder.

3. The size distribution for the fines collected on the inside of the Window from Procedure 1 above was measured using Microtrac. The fines were rinsed out of the window with dilute acid solution. 
4. Can the dust from Procedure 3 above be removed in a small number of processing steps and without the larger frit particles continuing to spall additional dust sized particles? The procedure was to run the LabRAM repeatedly with dry frit to see if nearly all frit fines could be removed by agitation and air purging. The filter paper and Window were typically weighed once per hour.

5. What particle size of frit is expected to create a dust problem? A significant problem for DWPF would be if dust plugged the SME condenser. No additional testing was done to answer this question however calculations were performed.

6. If particles below that size mentioned in the previous question are removed will bulk dust generation be eliminated or nearly eliminated? Bekeson Glass of Flowood MS and the Multi-Aspirator Co. of Wichita KS were both asked to remove particles smaller than approximately $37 \mu \mathrm{m}$ from DWPF frit. Visual tests of the three frits were performed to estimate the effectiveness of removing small particles on reducing dust generation when frit is poured. Three gallons (11 kg) each of DWPF Frit, Bekeson Frit and MultiAspirator Frit were obtained. Per Bekeson recommended procedure, three gallons of each type of frit were heated in an oven to drive off moisture, which can cause fines to stick to larger particles, confusing any comparison. (This was prudent because the weather had been rainy during the period of the tests.) To perform the test, a three gallon bucket of frit was lifted to an elevation of ten feet and the contents were poured into a container over a 20 second period. To enhance visual observation during video recording, a dark cloth had been placed behind the falling stream, and the stream was strongly lit from the side. The first test used both DWPF frit and Bekeson frit and the container was a 55 gallon drum that was half full of water. The water was to simulate pouring frit into aqueous slurry in the Slurry Mix Evaporator (SME).

\subsection{Quality Assurance}

This report fulfills the scope described in the Task Technical and Quality Assurance Plan [McCabe, 2013] SRNL-RP-2013-00134, March 2013, Rev. 0. Requirements for performing reviews of technical reports and the extent of review are established in manual E7 2.60. SRNL documents the extent and type of review using the SRNL Technical Report Design Checklist contained in WSRC-IM-2002-00011, Rev. 2.

\subsection{Results and Discussion}

\subsection{Will the addition of water greatly reduce dust generation?}

The procedure for this testing was summarized in Item 1 of Section 2.2 of this report and used the LabRam Dusting Apparatus, Figure 1, to test Frit 418 dust generation. During this test, air was drawn through the container, a glass Observation Window and a filter in a housing using a partial vacuum located downstream of the filter. The air flow rate was $400 \mathrm{sccm}$. At the conclusion of the ten minutes, there was no visible additional dust evolving from the frit. The container, the window and the filter paper (but not filter holder) were then reweighed. The container lost $80 \mathrm{mg}$, the filter paper gained $7 \mathrm{mg}$ and the window gained $30 \mathrm{mg}$ (the difference between the $80 \mathrm{mg}$ lost and the $37 \mathrm{mg}$ gained could be due to losses in the line and filter housing). The window was visually observed to contain glass frit particles, see the tube marked "dry” in Figure 2. 


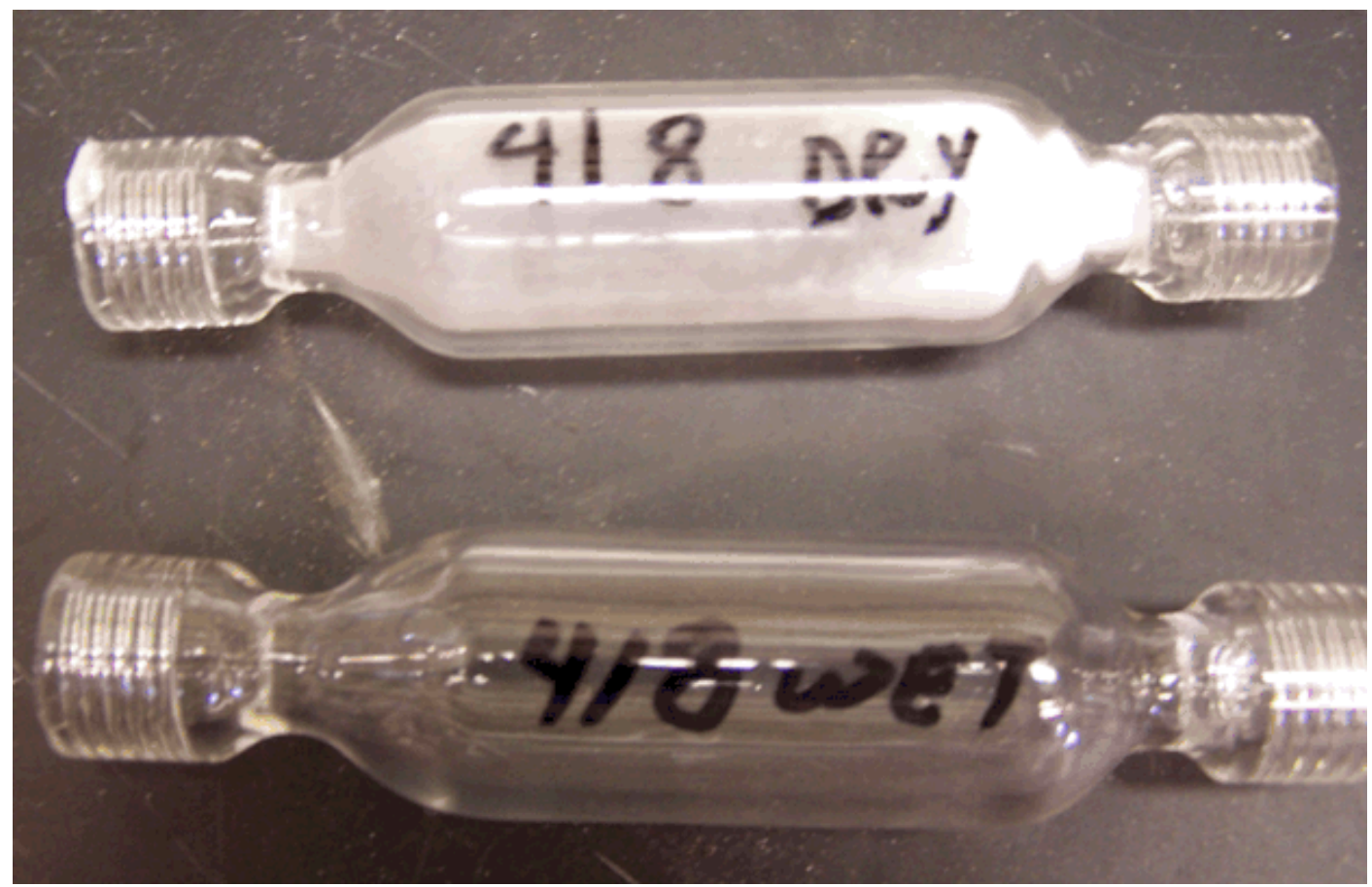

Figure 2

Observation Window Showing DWPF Frit 418 Dust from dry test (above, no water added) and wet test (below, water added)

This test was repeated with the addition of a small amount of water to the frit which was expected to reduce the release of fines. The water was injected using a syringe connected to the frit container with a tube. The syringe was loaded with $1.5 \mathrm{~g}$ of water to mix with $100 \mathrm{~g}$ of dry frit to give $1.5 \mathrm{wt} \%$. However, the partial vacuum inside the LabRAM chamber drew additional water from the connecting tube for a total of $2.4 \mathrm{~mL}$. Again, the frit was mixed at $10 \%$ intensity for ten minutes with continuous air flow at $400 \mathrm{sccm}$. No dust was observed inside the Window, see Figure 2 and the tube marked "wet", and the Window had no measurable weight gain. The filter paper had no weight change to within measurement accuracy. This test was repeated injecting the intended $1.5 \mathrm{~g}$ of water. Once again there was no visible frit inside the Window. There was no measurable weight increase for the filter paper or Window. Note that the filter housing was not weighed for this test, but no solids were visible in it after disassembly.

\subsection{If water is added will it cause the frit to clump?}

Damp samples of Frit 418 and Frit 320 were manually pressed into a mold, removed, and allowed to air dry in a fume hood overnight. Photographs of the dry cylinders of frit are shown in Figures 3 and 4. The damp cylinder of Frit 320 was removed from the mold first and some pieces broke off. Removal technique improved for the cylinder of Frit 418. The mass required to crush each dried cylinder was determined. A mass of 4 grams was sufficient to crush the Frit 418, so a clump of Frit 418 has almost no strength. A mass of 51 grams was not sufficient to crush the Frit 320, but 75 grams was sufficient. Therefore, Frit 320 has much more tendency to clump than Frit 418. This lab-scale test indicates that clumping of wetted, compacted, then dried Frit 418 should not be a problem. Because of this observation, the original plan for addition of acid to inhibit clumping was not pursued. 


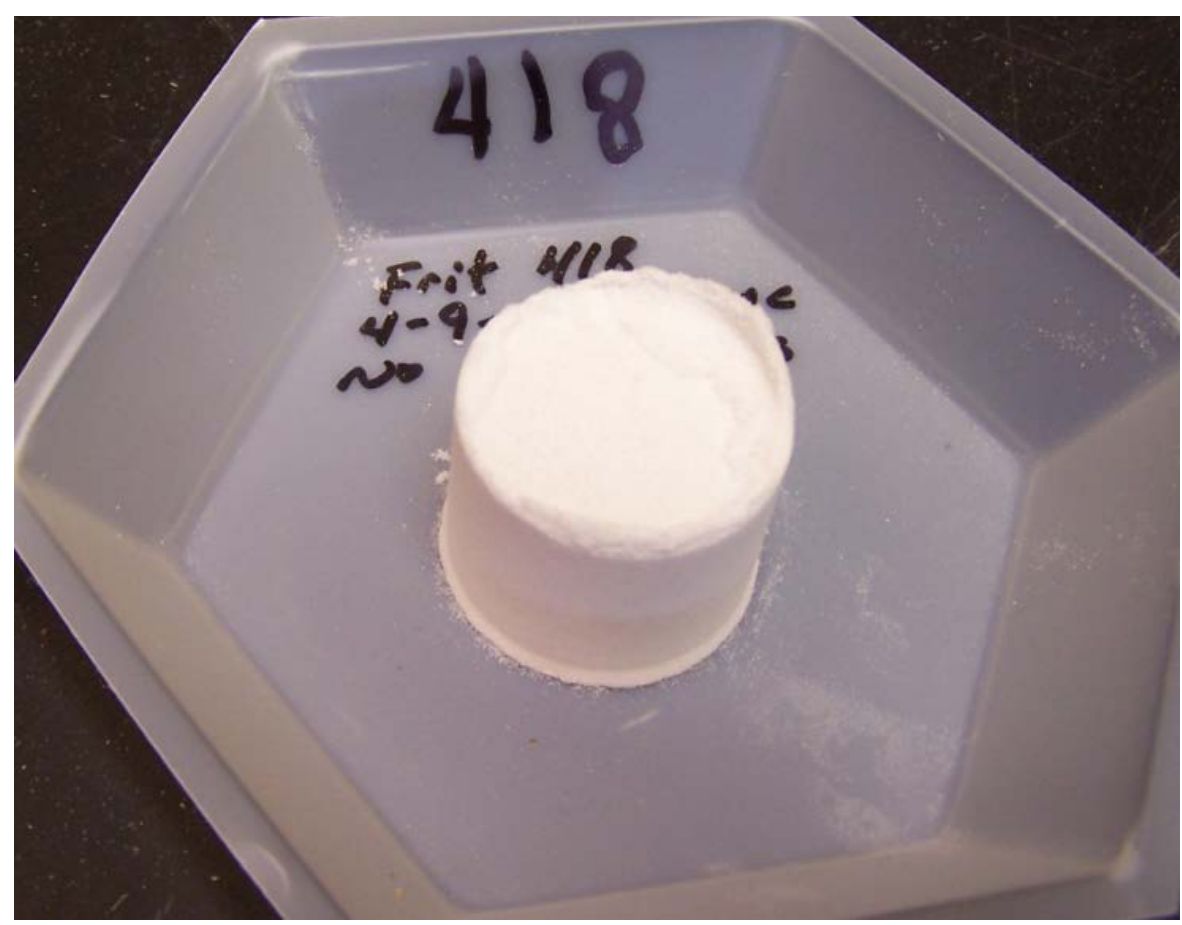

Figure $3 \quad$ Dried Cylinder of Frit 418

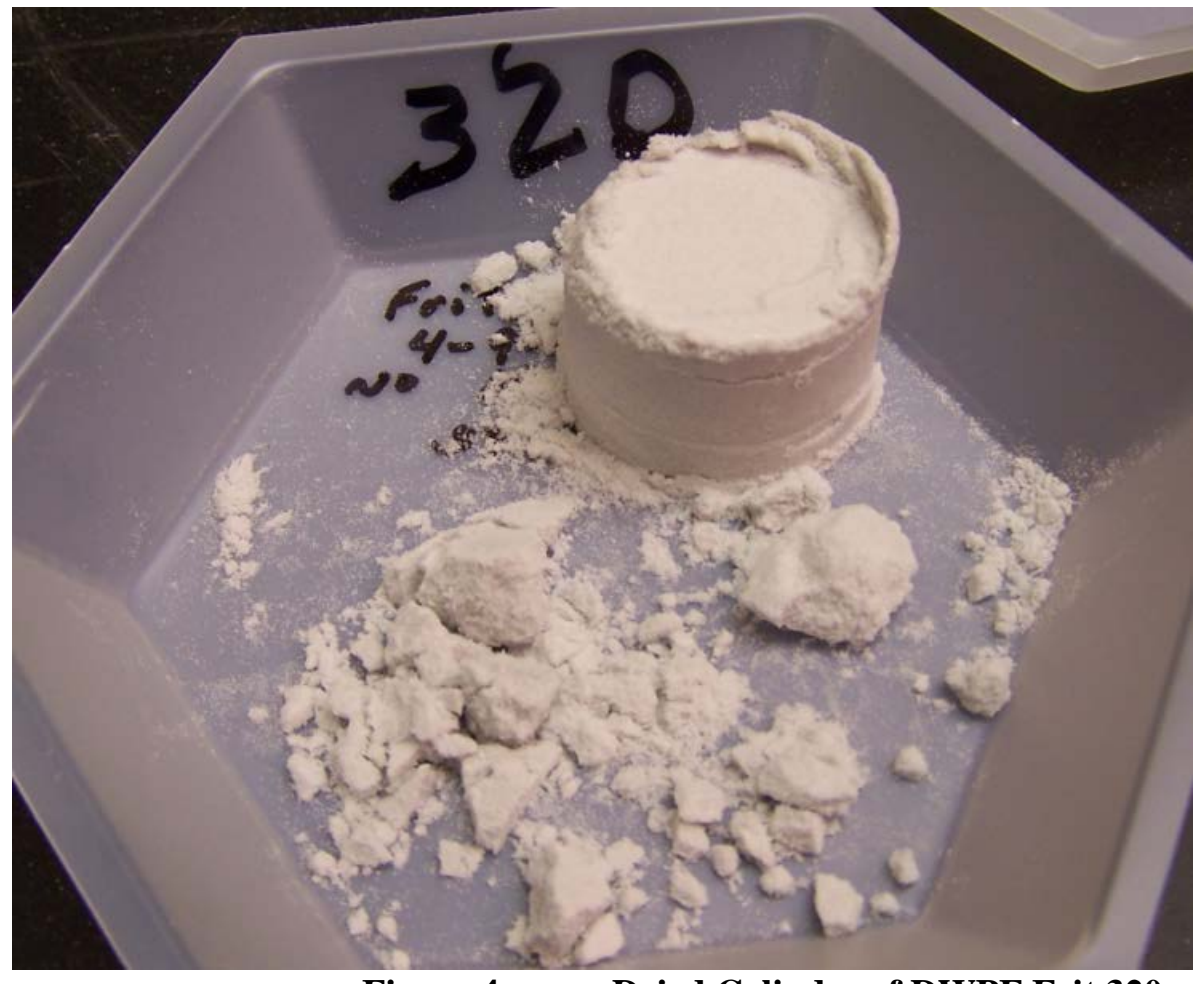

Figure $4 \quad$ Dried Cylinder of DWPF Frit 320

3.3 What is the size distribution of frit dust?

Section 3.1 of this report describes capturing frit fines generated when dry DWPF Frit 418 was shaken. Scanning Electron Microscopy (SEM) was used to image those fines captured on the inside surface of the glass Observation Window shown in the top of Figure 2, the 
window marked "418 Dry". That image is shown in Figure 5. In addition, $5 \mathrm{~mL}$ of dilute acid solution was used to wash out all of those fines from the window and Microtrac was used to compute a size distribution, see Figure 6. The median size on a volume basis was 7.6 $\mu \mathrm{m}$ and $95 \%$ of the frit particles were between 1.6 and $28 \mu \mathrm{m}$. (The size distribution of DWPF Frit 418, as-received, is shown in Figure 8). Particle sizes observed in the SEM image and the Microtrac size analyses are consistent.

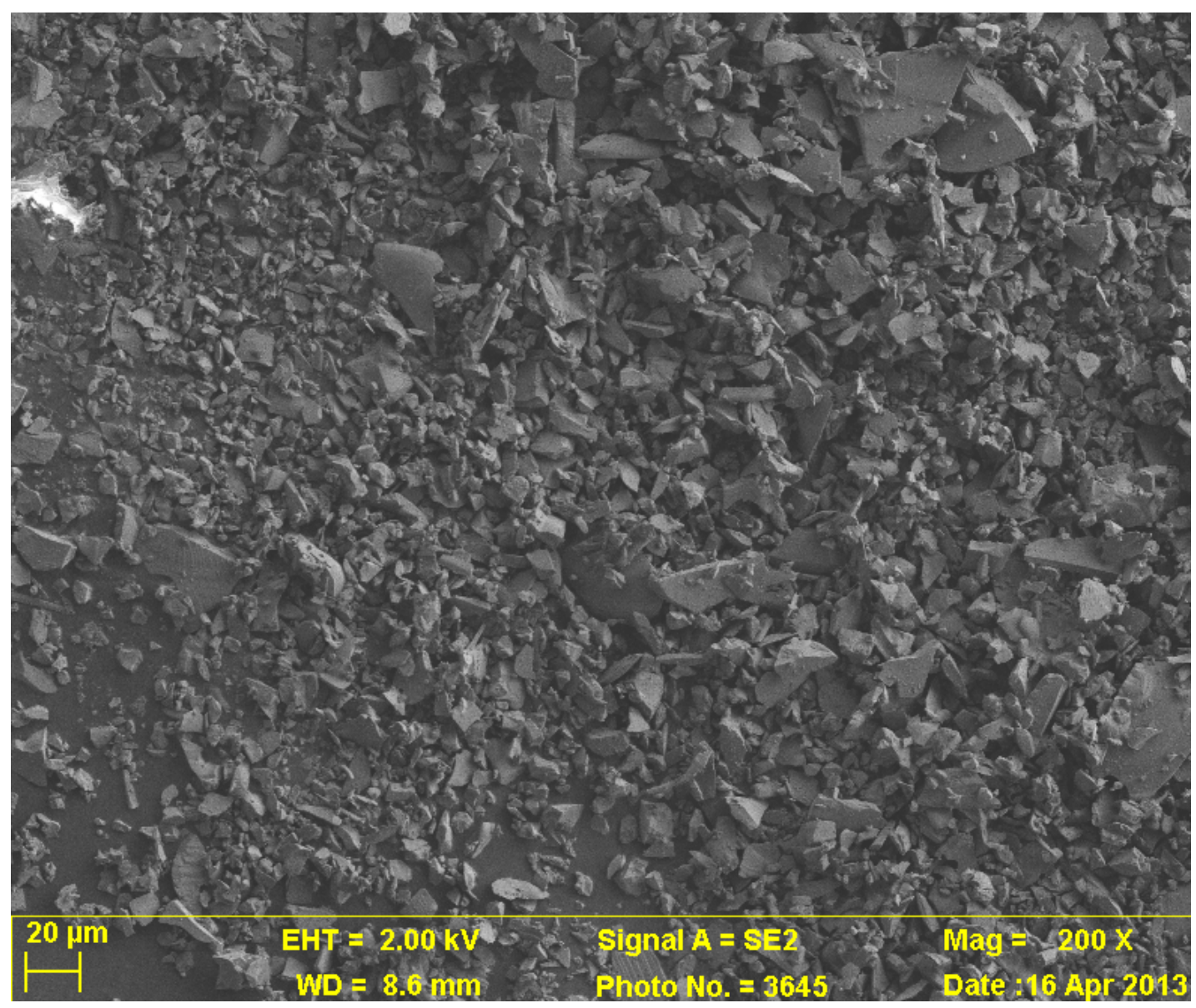

Figure 5 Scanning Electron Micrograph of Frit Dust from dry test collected in window. 
SRNL-STI-2013-00412

Revision 0

- Partic le Size Analysis -

\begin{tabular}{|lr|}
\hline Frit Fines & Data Acquired: 2013/04/23 - 08:44 \\
Steimke & Calculated: 2013/04/23 - 08:44 \\
\hline
\end{tabular}
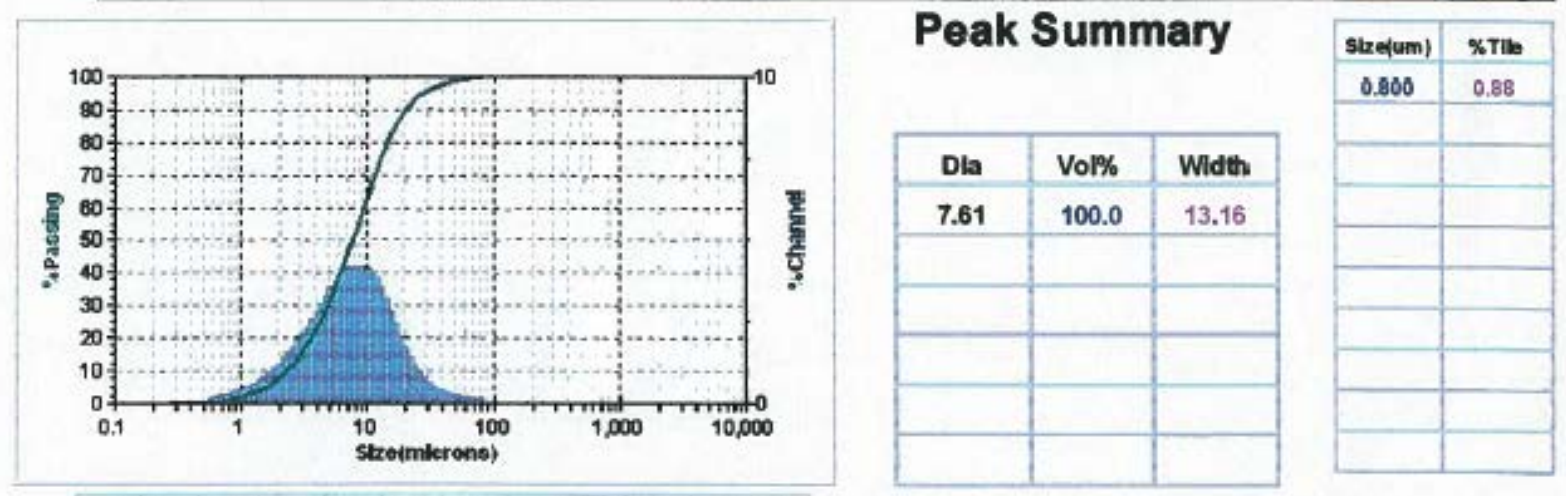

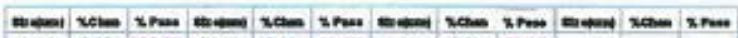

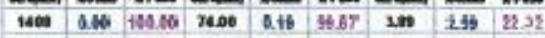

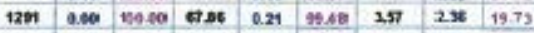

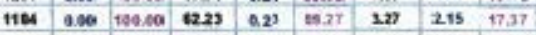

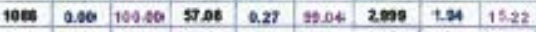

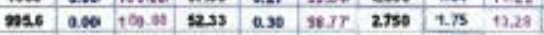

\begin{tabular}{|l|l|l|l|l|l|l|l|l|l|l|}
9120 & 0.00 & 100.50 & 958 & 0.35 & $38.4 T$ & 252 & 1.57 & 11.57 \\
\hline
\end{tabular}

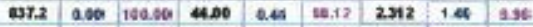

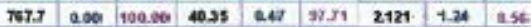

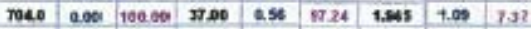

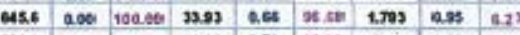

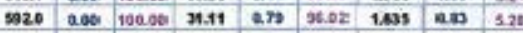

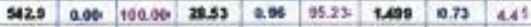

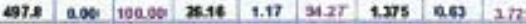

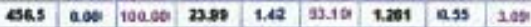

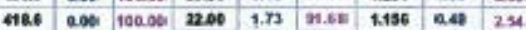

\begin{tabular}{|l|l|l|l|l|l|l|l|l|}
\hline 3020 & 2.06 & 100.00 & 2017 & 2.05 & 05.58 & 1.060 & 0.12 & 2.06 \\
\hline
\end{tabular}

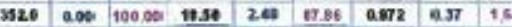

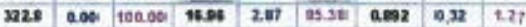

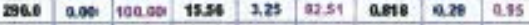

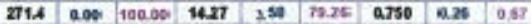

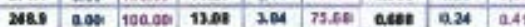

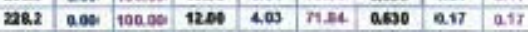

\begin{tabular}{|l|l|l|l|l|l|l|l|l|}
200.3 & a.96 & 100.00 & N1.00 & 4.15 & 67.81 & a.578 & 2.00 & 0.0 \\
\hline
\end{tabular}

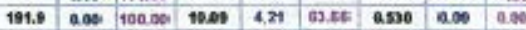

\begin{tabular}{|l|l|l|l|l|l|l|l|l|l|}
\hline 1760 & 0.06 & 100.00 & 2.25 & 4.18 & 53.45 & 0.285 & 200 & 0.90 \\
\hline
\end{tabular}

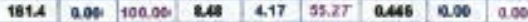

\begin{tabular}{|l|l|l|l|l|l|l|l|l|}
\hline 1420 & 0.00 & 100.00 & 7.70 & 4.11 & 5130 & 0.00 & 0.00 & 00 \\
\hline
\end{tabular}

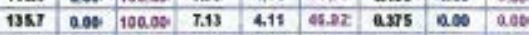

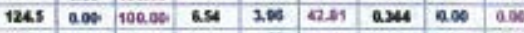

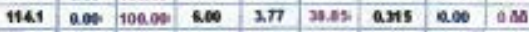

\begin{tabular}{|l|l|l|l|l|l|l|l|l|l|l|}
\hline 104.7 & 0.00 & 100.00 & 5.50 & 2.55 & 55.00 & a.2350 & 0.00 & 0.00 \\
\hline
\end{tabular}

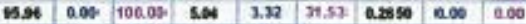

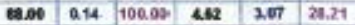

\begin{tabular}{|l|l|l|l|l|l|}
\hline 50.70 & a17 & 19.95 & 421 & 283 & 35.14 \\
\hline
\end{tabular}

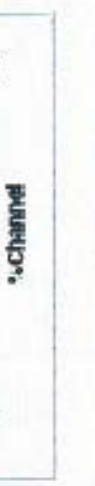

\section{Summary}

\begin{tabular}{|c|c|}
\hline Data kem & Value \\
\hline MV(um): & 10.35 \\
\hline$M N($ um): & 1.282 \\
\hline MA(um): & 4.92 \\
\hline CS: & 1.219 \\
\hline SD: & 6.58 \\
\hline & \\
\hline
\end{tabular}

\section{Percentiles}

\begin{tabular}{|c|c|}
\hline \%TIle & Size(um) \\
\hline 10.00 & 2.317 \\
\hline 16.00 & 3.10 \\
\hline 25.00 & 4.22 \\
\hline 40.00 & 6.15 \\
\hline 50.00 & 7.61 \\
\hline 60.00 & 9.36 \\
\hline 70.00 & 11.53 \\
\hline 75.00 & 12.88 \\
\hline 90.00 & 20.22 \\
\hline 95.00 & 27.92 \\
\hline
\end{tabular}

\begin{tabular}{|c|c|c|c|c|c|c|c|}
\hline Oineritudion: & Volumo & Aun Thes: & 30800 & muie & Warek & & \\
\hline frogrmalen: & Geom S Roce & Run Hum: & anveds & Feld Arot, indere & 1233 & Londing Focter: & 0000 \\
\hline Upper Edpes? & 1603 & Partcle: & MOAss Aas & Now Rostanes & 0 & Tranamberion: & 0.00 \\
\hline Lovert Edoes: & 0.243 & 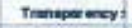 & Nenosting & Dotow Residuat & 0 & nus nonldiet & 4.20t-as \\
\hline nenstuds: & Disebied & Part het inser: & sia & & & now & $40 \times$ \\
\hline Mun= clantute: & $=0$ & Part theses: & inovise & Cadlis. & ases & Uneven pown: & ma \\
\hline Anetralio Nodes: & 20190 & & & & & Unevte Tine: & mas \\
\hline new: & Enstind & Bestecard: & 2252 & Rocele tineus: & & serien Hum: & s37s4 \\
\hline Andyale audn: & Datink & Penthens: & Expropran $n$ & crobence Futx 10. & ODoscatar & 2012 NDa & \\
\hline
\end{tabular}

Figure 6 Particle Size Distribution of Frit Dust 


\subsection{Can dust be removed from frit without generating fresh dust?}

Tests were performed with the LabRAM over a period of days to address this question but the results were inconclusive. A summary of the results are given here as a record. A list of samples collected is given in the Appendix C.

On April 17-18 the LabRAM was run repeatedly with dry frit to see if nearly all frit fines could be removed by agitation and air purging. The filter paper and Window were weighed once per hour and there were at least six one-hour runs. The expected decrease in mass of fines collected over time was not observed. In fact, the weight gain in the Window and filter paper for the fourth run on April 18 was greater than the total for the previous three runs. One contributing factor for the anomalous weight behavior was that the filter housing, which was not being weighed, contained frit and that frit was abruptly moving downstream as the test proceeded. Another contributing factor was the variation in relative humidity which changed the difficulty of dust separation.

Testing resumed on April 23 with two changes; the filter housing plus the filter were weighed and LabRAM intensity was increased to $16 \%$ to ensure a conservative test result. During three onehour runs, the filter and its housing gained $2.8 \mathrm{~g}, 1.8 \mathrm{~g}$ and $2.6 \mathrm{~g}$, respectively and the Observation Window gained $10 \mathrm{mg}, 7 \mathrm{mg}$ and $4 \mathrm{mg}$, respectively. The frit in the filter housing was retained for size analysis. The frit container lost a total of $8.1 \mathrm{~g}$ during the three runs compared to the measured gain of $7.2 \mathrm{~g}$, so there was an approximate mass balance. However, the anticipated trend of decreasing mass of fines in the filter was not observed. The apparent reason was that the intensity of $16 \%$ was causing mobilization and removal of frit particles that were within the acceptable size range distribution for frit, but were on the smaller end of the size distribution than average, in addition to much smaller particles, identified as "dust".

On April 24 the test was repeated with 10\% intensity and a fresh sample of Frit 418 . During the first run for 60 minutes, dust immediately appeared on the Observation Window but after 45 minutes the window cleared, indicating that the dust had moved downstream to the filter. The filter and housing captured $2.8 \mathrm{~g}$. At the end of the first run, video recordings of the frit container were initiated. Since the original frit container was scratched from use, the remaining frit from the first run was poured into another container. During the second run at $10 \%$ intensity for 60 minutes, there was no additional measurable mass loss in the frit container and no additional measurable mass gains in the observation window or filter housing. Therefore, that seemed to indicate that a one step process was sufficient to remove the dust particles and no additional dust particles were generated, as long as the mixing intensity remained at $10 \%$. Later the dust size distribution for the 2.8 grams of frit collected in the filter was measured and is shown in Figure 7. There is a small peak at $4 \mu \mathrm{m}$ and a large peak at $100 \mu \mathrm{m}$. The Microtrac analysis showed that of the dust collected by the filter, $91 \%$ of the total volume was in particles greater than $20 \mu \mathrm{m}$. The size distribution of the particles in the larger peak is not much smaller than the initial frit size distribution of DWPF Frit in Figure 8, indicating that "average" frit was being aerosolized, so it would have been expected that more frit would have continued to be aerosolized and captured in the filter with additional one hour runs. The absence of additional frit captured in the filter during the second run seems inconsistent and cannot yet be explained. 


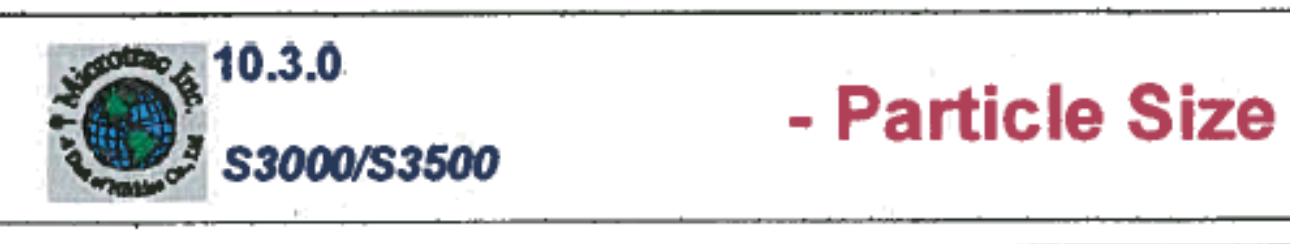

\section{$10 \%$ Fines}

Steimke

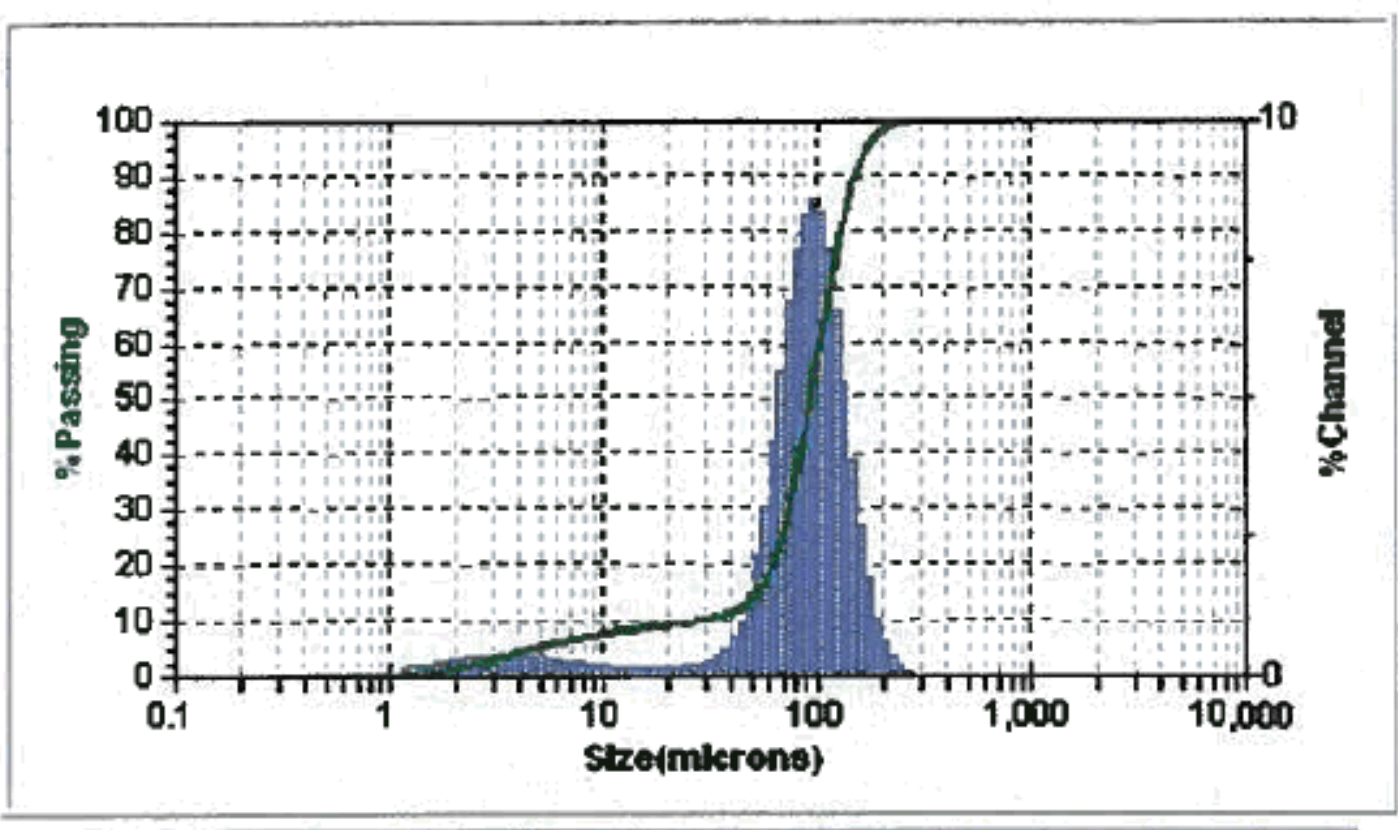

\section{Figure 7 Bimodal Frit Size Distribution from frit dust collected at $\mathbf{1 0 \%}$ intensity for extended duration}

Because of the unexpected results additional small scale de-dusting tests were started on May 21. The intention was to learn if the LabRAM could be used to de-dust frit. This testing was first performed with Bekeson frit, so most of the finest particles had already been removed. A small sample of Bekeson Frit 418 was submitted for Microtrac size analysis (Figure 8). Then, one hundred grams of fresh Bekeson frit were loaded in the LabRAM. The plan was to make three one-hour runs at $6 \%$ intensity or more runs if dust was still being collected on the filter and holder. Then increase to $8 \%$ intensity and perform more runs. Then increase to $10 \%$ intensity. However, it was learned that the LabRAM will not operate with the intensity less than $10 \%$. Bekeson 418 frit was run in the LabRAM for one hour at $10 \%$ intensity. Negligible fines were collected in the Observation Window, not surprising in light of Bekeson's fines removal, and a sample of the frit remaining in the LabRAM was submitted for Microtrac. The LabRAM intensity was increased to $12 \%, 137 \mathrm{mg}$ of fines were collected and sample of the frit remaining in the LabRAM container was collected. On May 22 the LabRAM intensity was increased to 14\%, $151 \mathrm{mg}$ of frit fines was collected in housing and a fines sample was collected. After a second run at these conditions only $13 \mathrm{mg}$ of fines was collected. 
Later on May 22 the LabRAM was charged with a fresh batch of original DWPF Frit 418. After the first run at $10 \%$ for one hour, $6 \mathrm{~g}$ frit fines were collected in the window, filter and filter holder. After the second run at those conditions 2.9 g were collected. On May 23 the same conditions were repeated two more times, collecting $2.4 \mathrm{~g}$ both times. On May 28, a continuation of the test was run re-using the frit from May 23 and an additional $6.25 \mathrm{~g}$ of frit was collected in the holder, an unexpected result. The unexpected result may have been caused by changes in humidity. Then this line of testing was discontinued.

\subsection{What particle size of dust creates a problem?}

A draft specification for the purchase of glass frit stated $<2 \%$ retained on 80 mesh $(180 \mu \mathrm{m})$, $<10 \%$ pass 200 mesh $(76 \mu \mathrm{m})$ and $<1 \%$ pass 400 mesh $(37 \mu \mathrm{m})$. For discussion purposes for this document, 400 mesh is a reasonable definition for "dust" for three reasons:

1. Almost all of the dust collected in the glass tube shown in Figure 2 was smaller than $37 \mu \mathrm{m}$.

2. The particle size distribution measured as-received Frit 418 has a bi-modal distribution and 37 $\mu \mathrm{m}$ divides the modes, see DWPF Frit 418 in Figures 8 and 9, which plot the same data.

3. A typical air velocity in a room is $1 \mathrm{ft} / \mathrm{sec}$ [McQuiston and Parker, 1982], although it is higher in front of a vent or fan. Roughly speaking dust will travel a significant distance if the terminal velocity in air is less than one-fourth of the lateral air velocity. As shown in Figure 10, the particle size with density $2.5 \mathrm{~g} / \mathrm{mL}$ that has a terminal velocity in air equal to $0.25 \mathrm{ft} / \mathrm{s}$ is $32 \mu \mathrm{m}$.

However, this does not mean that the aforementioned draft specification is sufficient for prevention of clogging of filters or ventilation components at DWPF. Determining that is beyond the scope of this test program, and would require an engineering evaluation of the specific equipment geometry, air velocities, pneumatic transfer velocity perturbations, and off-gas handling system and down-stream capacities for tolerating dust. 


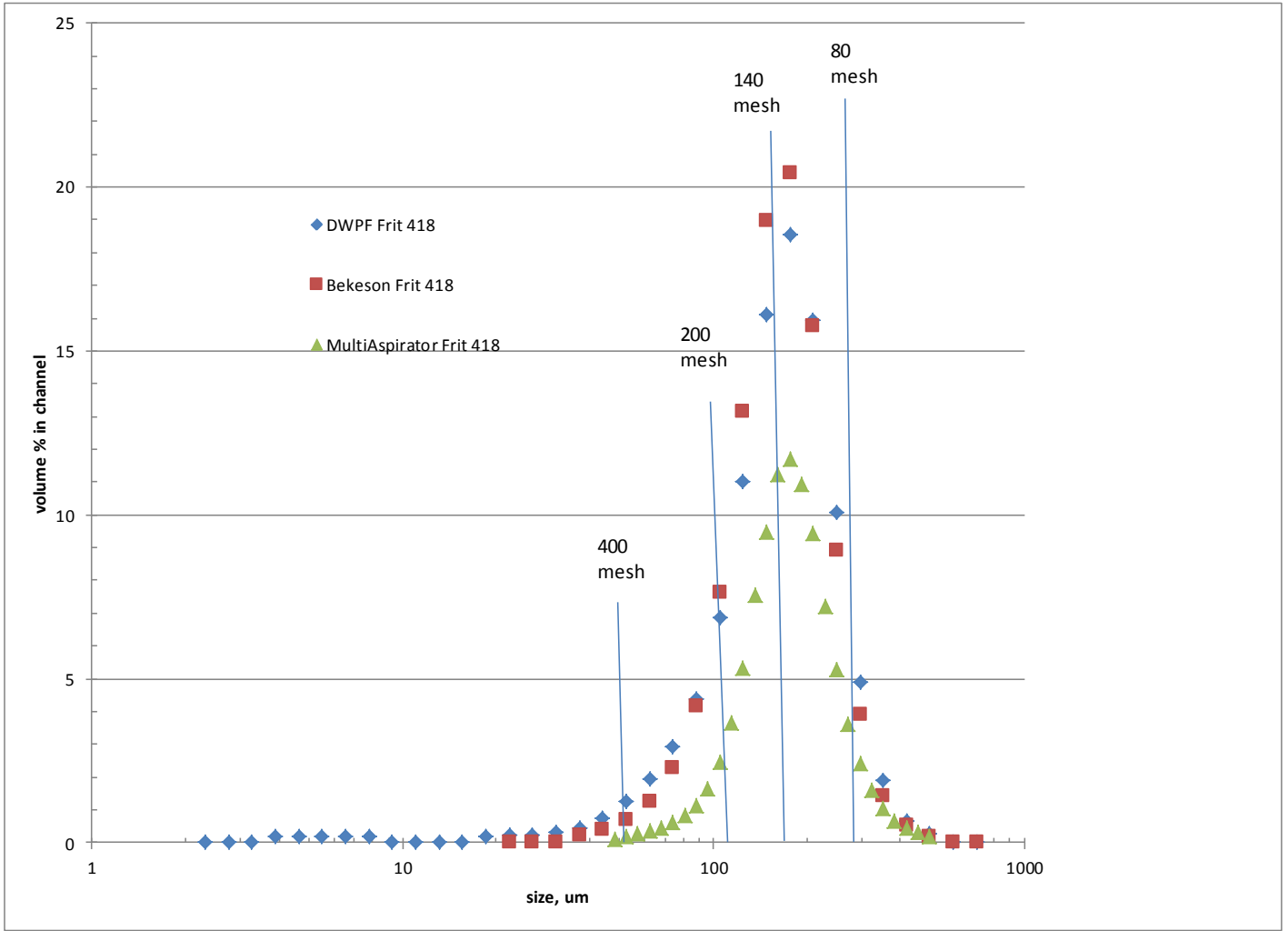

Figure 8 Size Distributions for Three Types of Frit, Full Scale 
SRNL-STI-2013-00412

Revision 0

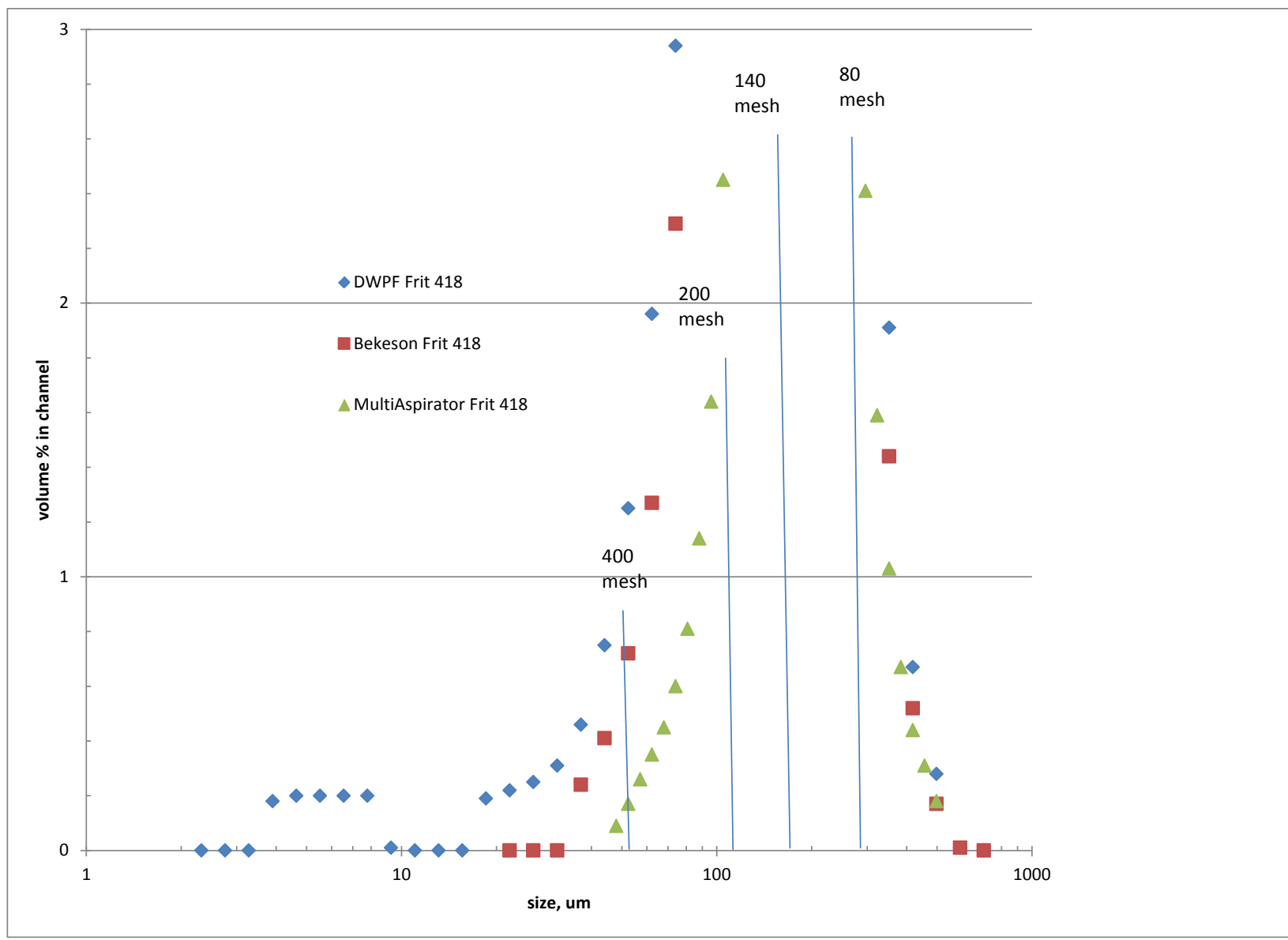

Figure 9 Size Distributions for Three Types of Frit, Expanded Scale 
SRNL-STI-2013-00412

Revision 0

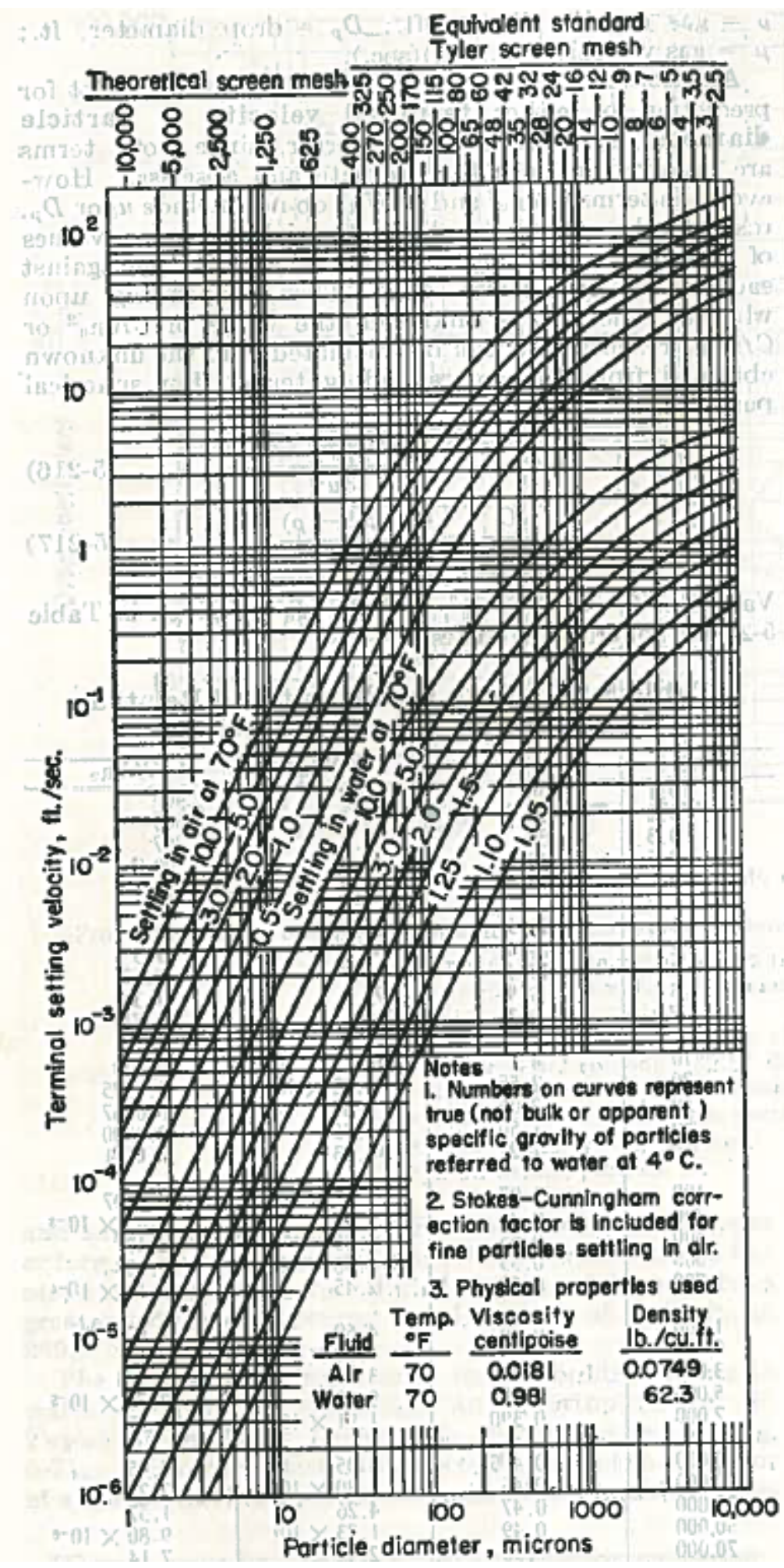

Figure 10 Terminal Velocities for Sphere in Air and Water 


\subsection{Can removal of small particles eliminate or nearly eliminate dust generation?}

Bekeson Glass of Flowood MS and the Multi-Aspirator Co. of Wichita KS were both asked to remove particles smaller than approximately $37 \mu \mathrm{m}$ from DWPF frit. Small samples of both frits and an unaltered DWPF Frit 418 were analyzed by Microtrac for size distributions and the results are plotted above. Figure 8 shows the complete size distributions while Figure 9 expands the y axis to emphasize the size distributions for the smallest particles. The Bekeson and the MultiAspirator de-dusting processes were very successful and removed particles less than $34 \mu \mathrm{m}$ to the level of detection of the Microtrac. The Microtrac operator must input a window size to the machine, for example a factor of 1.2 window size gives size ranges of $10 \mu \mathrm{m}$ to $12 \mu \mathrm{m}, 12 \mu \mathrm{m}$ to $14.4 \mu \mathrm{m}, 14.4 \mu \mathrm{m}$ to $17.3 \mu \mathrm{m}$, etc. The window size used for the Multi-Aspirator frit size analysis was half as large as the window size used for the other two analyses so the y values should be about half as much. Taking that fact into account the Multi-Aspirator frit has a sharper cut for smaller sizes.

Visual tests of the three frits were performed on June 5 and June 13, 2013 to estimate the effectiveness of removing small particles on reducing dust generation in a simple geometry when frit is poured. Three gallons (11 kg) each of DWPF Frit, Bekeson Frit and Multi-Aspirator Frit were obtained. Per Bekeson recommended procedure, three gallons of each type of frit were heated in an oven to drive off moisture, which can cause fines to stick to larger particles, invalidating any comparison. (This was prudent because the weather had been rainy during the period of the tests.) To perform the test, a three gallon bucket of frit was lifted to an elevation of ten feet and the contents were poured into a container over a 20 second period. To enhance visual observation during video recording, a dark cloth had been placed behind the falling stream, and the stream was strongly lit from the side. The first test used both DWPF frit and Bekeson frit and the receiving container was a 55 gallon drum that was half full of water and slowly agitated. The water was to simulate pouring frit into liquid in the Slurry Mix Evaporator (SME). Pouring the original DWPF frit 418 (no fines removal) generated a huge dust cloud. Pouring the Bekeson frit resulted in much less dust, but there was still an appreciable amount.

After this test it was recognized that the falling streams of frit entrained air with them. Because of the air volume mobilized downward in the falling stream and displacement of air volume by the moving frit particles, a significant amount of air had to flow up and out of the drum. Because the cross-sectional area of the drum was small, hindering the outward flow of air, the upward air velocity was high, causing more frit to be entrained as a dust cloud. Therefore a second series of tests were performed on June 13 when DWPF frit and Multi-Aspirator frit were poured into a tank that was 62" square and 30" high. As before, the receiving tank was half filled with water that was being slowly agitated with a pump. The frit immediately sank upon hitting the water, with no accumulation of dry solids. The amount of dust entrainment observed when pouring the DWPF frit was greatly reduced compared with the previous test that used a drum. The mass of dust with the Multi-Aspirator frit was less than with the original DWPF Frit 418, but cannot be compared to Bekeson frit because there was insufficient Bekeson frit on hand.

There are two steps in dust entrainment during handling in a full-scale system. The first step is caused by the previously mentioned updraft generated by falling frit. The second step lasts longer and is caused by ambient air currents unrelated to the falling frit. A limitation of the frit pouring tests documented in this section is that both the initial updraft and the later ambient air currents will be different in the SME. The initial updraft is expected to be weaker in the SME because it has a larger cross sectional area than either of the test tanks. However, the ambient air currents will not necessarily be weaker in the SME. The ambient air currents in the ACTL tests were the results of a nearby hood and building air conditioning. The ambient air currents in the SME are 
the result of air purging, air movement resulting from condenser action and the pneumatic addition system configuration and accompanying mobilization air flow.

These frit pouring test results suggest that sufficient dust particles either remained with the frit after the vendor de-dusting to cause visible dust, or that some particles larger than $37 \mu \mathrm{m}$ still appear to be sufficiently small to generate appreciable visible dust. So this question was not conclusively answered.

\subsection{Can dry frit be poured into the SME without plugging the condenser?}

Sections 3.1 through 3.6 of this report presented results. However, this section makes a recommendation.

DWPF has been pursuing dry frit addition to the Slurry Mix Evaporator (SME). One concern is that frit dust will accumulate in the condenser of the SME. DWPF requested computation of the amount of frit that would accumulate using the results from small scale tests. This has not been performed because estimating the many unknowns for a demonstrably conservative calculation based on current information is expected to conclude an unacceptably large amount of frit would accumulate in the condenser. Part of the complication in calculation stems from the fact that falling frit entrains air and generates an updraft. The velocity of the updraft will depend on the size and shape of the containment which was not mocked to scale in this testing. In addition, air from the SME is drawn into the condenser, which was also not simulated in these tests. However, a full size SME test would have all important features and be able to defensibly quantify the frit that accumulates in the condenser.

The concept is to build a full scale SME replica. A nearly circular framework 12 ' in diameter would be constructed from 3/4" PVC pipe and glue joint tees. The height of the cylinder is two feet greater than the typical distance from the slurry to the top of the SME. A tank is placed under the SME framework and half filled with water. The circumference of the SME framework is covered with clear plastic. The top of the SME is covered with plywood or acrylic. The top has holes at the correct radial and angular positions for the condenser simulator, for frit addition and for purge air. The condenser hole is connected to a cardboard tube (e.g., the type used for casting concrete footings). This tube also contains a commercial cloth bag filter. The top of the condenser assembly is connected to a blower with an orifice air flow rate meter in the line. Cardboard or PVC tubes are used to achieve the correct geometry at the frit addition and purge air flows.

Tests would be conducted in the following manner: First operation and illumination is checked with a small quantity of frit. A bag filter is dried, weighed and installed in the location otherwise occupied by the condenser. Air flows (condenser, purge and frit mobilization) are adjusted with dampers to match the flows in the engineering report [Chang, 2010]. Lighting and camera are started and frit is poured into the frit injection port along with frit moving air, ( 66 scfm per Chang). After all frit is poured, the camera is stopped, the bag filter is removed, dried and weighed.

\subsection{Conclusions / Recommendations}

1. Clumping of frit after addition of $1.5 \mathrm{wt} \%$ water is not expected with DWPF Frit 418 or other frits with similar alkali/silica content and particle size distribution. However, this testing did not investigate the time and geometry of a large-scale system, where flowing air could re-dry the frit and thereby re-aerosolize the dust, or where the water addition may not be homogeneous. 
2. Frit 418 that has been treated by the vendors to remove the finer particles, shows promise for dry frit addition to the SME and dusting has been significantly reduced with the treated frit in small scale tests. However, the tests performed to date have all indicated some residual dust generation with dry frit. Furthermore, these tests have not been sufficiently prototypical to reproduce the air currents that would be generated inside the SME when a stream of frit is poured into it, and have not yielded quantitative results.

3. DWPF-Engineering has proposed changing the 200 mesh $(76 \mu \mathrm{m})$ lower size limit to 170 mesh $(89 \mu \mathrm{m})$ to mitigate dusting. This change is expected to reduce dust generation, but the amount of reduction is not quantifiable with existing data, and it is not known if this is sufficient. The proposed change tightens the specification rather than expanding it, therefore adverse impacts on other processing parameters (e.g. melt rate), although not expected, have not been tested.

4. Tests are recommended using a vessel having the similar dimensions as the top half of the SME, at similar air flows, and having a method to capture fines in the location where the SME has a condenser. An engineering evaluation is then needed to determine if coupling this test system with the proposed pneumatic conveyance system or any part of the off-gas system is required to accurately assess the integrated impacts. Further detailed evaluation is also needed on the acceptable amount of dust that would be tolerable in the off-gas system and downstream processes (e.g., the scrubbed dust from the condenser will end up in the Tank Farms, potentially causing impacts).

\subsection{References}

M. R. Baron, “Bulk Frit Handling”, DPST-87-238, 1987.

Chang, R.C., "Evaluating the Impact of SME Dry Frit Conveying Project in DWPF PVV System Processes”, X-ESR-S-00037, 2010.

D. C. Iverson, “Glass Frit Handling Experience at SRL”, DPST-83-250, 1983.

M. W. Lambert and E. K. Hansen, "The Use of DI Water to Mitigate Dusting for Addition of DWPF Frit to the Slurry Mix Evaporator”, SRNL-STI-2010-00421, 2010.

D. J. McCabe and M. E. Stone, "TTQAP for Testing to Determine Options for Dust Mitigation in the SME for the Dry Frit Addition Project”, SRNL-RP-2013-00134, March 2013.

F. C. McQuiston and J. D. Parker, “Heating, Ventilating and Air Conditioning”, 1982. 


\title{
Appendix A. R\&D directions for Scoping Test of LabRAM Dust Evaluation Apparatus
}

\author{
PI J. L. Steimke \\ Alternate $\quad$ M. E. Stone \\ Speed Chart $\quad$ 033NL4W300 \\ eHAP SRNL-L3100-2008-00081-2 \\ Task Plan SRNL-RP-2013-00134 \\ Hazards Moving and Rotating Equipment \\ Controls Tests will be performed in a fume hood \\ Labcoats, nitrile gloves, and safety glasses shall be worn \\ Objective This test will evaluate the effectiveness of the Dusting Evaluation Apparatus in \\ detecting and collecting dust from DWPF process frits. \\ The following steps will be used to perform the tests: \\ 1) Tare filter paper and observation window. \\ 2) Install filter paper and observation window as shown in Figure 1. \\ 3) Add 100 grams of Frit 418 to a tared polycarbonate container \\ 4) Install container in LabRAM as shown in Figure 1. \\ 5) Turn on light for observation window and start camera. \\ 6) Mix container of frit in the LabRAM as specified by PI. \\ 7) Turn on vacuum and set flow rate on inlet air to $400 \mathrm{sccm}$. \\ 8) Record mixing intensity. \\ 9) Record observations such as dust in the Observation Window. \\ 10) Record observations. \\ 11) Turn off vacuum, camera and backlight. \\ 12) Monitor air inlet flow until it approaches zero. \\ 13) Remove and weight filter paper and observation window. \\ 14) Record weight of frit container. \\ 15) Repeat steps 1 through 14 with one exception, between steps 6 and 7 inject $1.5 \mathrm{~g}$ of water.
}

No water addition

\begin{tabular}{|l|l|l|l|}
\hline & Frit container & Filter paper & window \\
\hline Tare, g & 78.814 & 0.143 & 39.771 \\
\hline Weight after frit, g & 178.815 & & \\
\hline Water addition, g & 0 & & \\
\hline LABRAM and air start & $9: 21$ & & \\
\hline LABRAM intensity & $10 \%$ & & \\
\hline LABRAM g & 3 & & \\
\hline LABRAM stop & $9: 31$ & & \\
\hline Final wt, g & 178.735 & 0.150 & 39.801 \\
\hline Weight change, g & -0.08 & +0.01 & +.03 \\
\hline
\end{tabular}


$2.4 \mathrm{~g}$ water addition, $2.4 \%$ by mass

\begin{tabular}{|l|l|l|l|}
\hline \multicolumn{1}{|l|}{} & Frit container & Filter paper & window \\
\hline Tare, g & 78.854 & 0.112 & 41.007 \\
\hline Weight after frit, g & 178.856 & & \\
\hline Water addition, g & 2.4 & & \\
\hline $\begin{array}{l}\text { LABRAM and water } \\
\text { start }\end{array}$ & $10: 08$ & & \\
\hline LABRAM inten, \% & 10 & & \\
\hline LABRAM, g & 6 & & \\
\hline Air flow start & $10: 13$ & & \\
\hline LABRAM and air stop & $10: 23$ & & \\
\hline Final wt, g & na & 0.085 & 41.008 \\
\hline Weight change, g & na & 0.027 & 0.001 \\
\hline
\end{tabular}

G

$1.5 \mathrm{~g}$ water addition, $1.5 \%$ by mass

\begin{tabular}{|l|l|l|l|}
\hline & Frit container & Filter paper & window \\
\hline Tare, g & 78.815 & 0.087 & 40.870 \\
\hline Weight after frit, g & 178.813 & & \\
\hline Water addition, g & 1.5 & & \\
\hline $\begin{array}{l}\text { LABRAM and water } \\
\text { start }\end{array}$ & $10: 47$ & & \\
\hline LABRAM inten, \% & 10 & & \\
\hline LABRAM, g & 7 & & \\
\hline Air flow start & $10: 52$ & & \\
\hline LABRAM and air stop & $11: 02$ & & \\
\hline Final wt, g & na & 0.087 & 40.871 \\
\hline Weight change, g & na & 0 & 0.001 \\
\hline
\end{tabular}

Scale used: ACTL BL-02 
SRNL-STI-2013-00412

Revision 0

\section{Appendix B R\&D Direction for Clumping}

R\&D Directions for Determination of Clumping in Frit 418 and Frit 320 System
PI
J. L. Steimke
Alternate
M. E. Stone
Speed Chart
033NL4W300
eHAP
SRNL-L3100-2008-00081-2
Task Plan
SRNL-RP-2013-00134
HazardsN/A
Controls Labcoats, nitrile gloves, and safety glasses shall be worn
Objective This test will evaluate the impact of the addition of 1.5 wt\% water to Frit 418 and Frit 320 systems.

The following steps will be used to perform the tests:

1) Prepare a form by cutting off the bottom of a tapered plastic $25 \mathrm{~mL}$ dilution vial. The plastic cap should stay on.

2) Add 25 grams of Frit 418 to a tared, labeled bottle. Repeat with Frit 320.

3) Add 0.375 grams of water to each bottle and mix well with a plastic spatula until frit is uniformly moist.

4) Use the spatula to transfer the damp Frit 418 to the inverted form and press into form with pestle, but not enough to crush the frit.

5) Hold the inverted form over a small labeled sheet of plastic or metal. Remove the plastic cap and use the pestle to gently press the frit out and onto the sheet.

6) Repeat the previous two steps with the Frit 320.

7) Allow both frit samples to dry in fume hood overnight.

8) Photograph both mounds.

9) Probe both frit samples and quantify as well as possible how hard they are. For example, is the weight of the spatula or the pestle sufficient to collapse the mound?

10) Photograph both collapsed mounds.

Technician: David Healy 
SRNL-STI-2013-00412

Revision 0

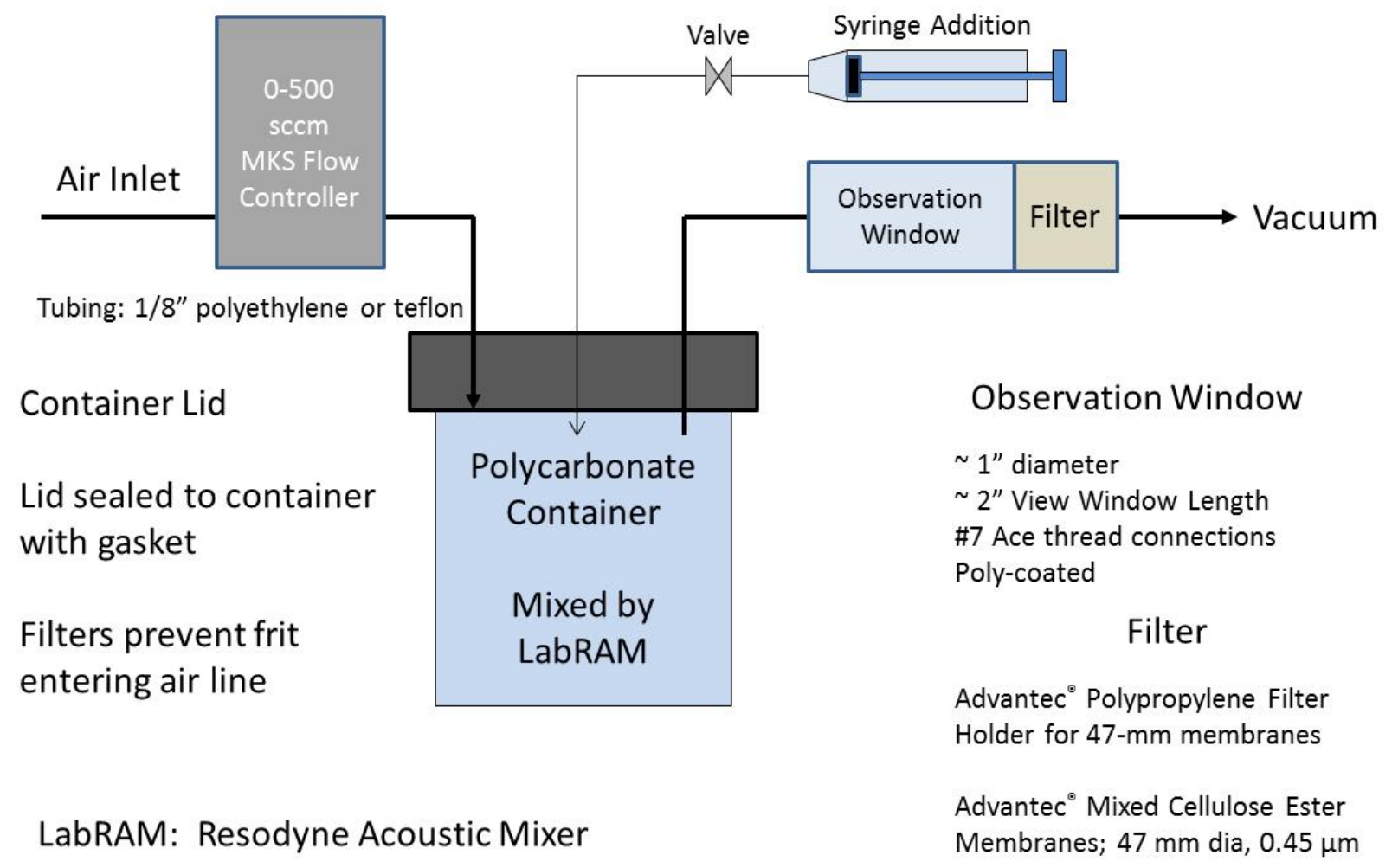


SRNL-STI-2013-00412

Revision 0

\section{Appendix C Sample list from LabRAM Runs}

May 21, 2013

Sample “Bekeson Frit 418 original” Microtrac 5/30

Run \#1 6\% Bekeson 418 frit, log sheet LabRAM will not work below 10\%, no fines sample

Run \#1@10\% Bekeson 418 frit, log sheet tiny amounts moved, not enough for fines sample, frit sample "Bekeson frit after 1 hour at 10\%, 5/21/13”,, Microtrac “Bekeson frit 1 hr 10\%” 5/30

Run \#1 at 12\% Bekeson 418 frit, log sheet, $137 \mathrm{mg}$ in housing, not enough for a sample, frit sample "Bekeson frit after 1 hour at 12\%, 5/21/13" , Microtrac "Bekeson frit 1 hr 12\%

Frit sample after two hours at 14\%, "Bekeson frit after 2 hours at 14\%, 5/21/13”, Microtrac "Bekeson frit 2 hr 14\%" 5/30

May 22, 2013

Run \#1@14\% Bekeson 418 log sheet, 9:50, log sheet 151 mg in housing, fines were collected "Bekeson Frit 14\% fines

Run \#2 @14\% Bekeson 418 log sheet, 11:05 13 mg gain in holder, no fines sample,

“Frit 418 A/R” Microtrac 5/30

Run \#1 @10\%, DWPF Frit 418, 13:18, 6 g in holder, fines labeled DWPF frit 418, fines, 5/22/13 Run \#1 10\%

Run \#2 @10\%, DWPF frit 418, 14:26, 2.9 g in holder, fines labeled DWPF frit 418, fines, 5/22/13 Run \#2 10\%

$5 / 23 / 13$

Run \#3 @10\%, DWPF frit 418, 8:35, 2.4 g in holder, fines labeled DWPF frit 418, fines, 5/22/13 Run \#3 10\%

Run \#4 @10\%, DWPF frit 418, 9:40, 2.4 g in holder, fines labeled DWPF frit 418, fines, 5/22/13

Run \#4 10\%, after this run others needed the LabRAM so frit equipment was removed.

$5 / 28 / 13$

Run \#5 @10\%, DWPF frit 418, 7:03, 6.35 g in holder, fines labeled DWPF frit 418, fines, 5/22/13 Run \#5 10\%, 


\section{Distribution:}

S. L. Marra, 773-A

T. B. Brown, 773-A

D. R. Click, 999-W

S. D. Fink, 773-A

C. C. Herman, 773-A

E. N. Hoffman, 999-W

F. M. Pennebaker, 773-42A

W. R. Wilmarth, 773-A

Records Administration (EDWS)

J. M. Bricker, 704-27S

T. L. Fellinger, 704-26S

P, J. Flores, 704-S

E. J. Freed, 704-S

J. M. Gillam, 766-H

B. A. Hamm, 766-H

E. W. Holtzscheiter, 704-15S

R. C. Hopkins, 704-30S

J. F. Iaukea, 704-27S

D. W. McImoyle, 766-H

J. E. Occhipinti, 704-56H

D. K. Peeler, 999-W

W. E. Pepper, 704-S

J. W. Ray, 704-S

P. J. Ryan, 704-30S

H. B. Shah, 766-H

D. C. Sherburne, 704-S

M. E. Stone, 999-W

S. J. Strohmeier, 704-15S

S. C. Tester, 704-27S 